\title{
Quality Control Management Of Madrasah Education In International Standard
}

\author{
Indah Komsiyah \\ Universitas Islam Negeri Sayyid Ali Rahmatullah Tulungagung, Indonesia \\ ${ }^{*}$ Corresponding author: \\ Email: indahkomsyah@yahoo.com
}

\begin{abstract}
.
Quality control has to design in educational institutions. The purpose of this study was to determine the concept of quality control of education at the International Standard Madrasah Amanatul Ummah Pacet Mojokerto, East Java. This research is qualitative research with a single case study model. The participants involved are 1) kyai, 2) madrasa heads, 3) vice coordinators of Madrasas, 4) ustadzor teachers in Madrasas, 5) students, and 6) alumni. The data collection process is 1) in-depth interviews; 2) participant observation; and 3) documentation studies. Data analysis data used l) data reduction, 2) data display; and 3) conclusion drawing/verification. The finding shows that the quality control process at the International Standard Madrasah Amanatul Ummah includes, 1) monitoring of activity programs is carried out in a coordinated and responsible manner; 2) a series of evaluations carried out intensely; 3) carry out control of order and program implementation continuously; 4) activity report in written form in the form of reporting and verbally in the form of directions; 5) carry out continuous monitoring. While transcendent control is a form of inherent supervision that is embedded in the religious spirit of each person relying on the Substance of the Almighty Creator. The control of improving the quality of education carried out by the Amanatul Ummah International Standard Madrasah is internal and transcendent control.
\end{abstract}

Keywords: Education, International Standards, Management, Madrasah, Quality Control

\section{INTRODUCTION}

Madrasah is the oldest formal Islamic education institution in Indonesia. Although madrasas are not native Indonesian educational institutions, the formality of madrasas has been standardized by the National Education Standards. Madrasas as Islamic educational institutions have characteristics whose activities are coloured by Islamic values. This particularity is considered positively by the community because of its ability to respond to the needs of today's society. Community participation in the development of madrasabased management can grow and develop in conditions of openness because of the mutual trust between the madrasa and the community(Anwar et al., 2019). There are quite aseveral Madrasahs in Indonesia. However, most of them have not received optimal management. This is evidenced by the condition of the madrasa which is only oriented to the fulfilment of crucial cognitive needs. Therefore, quality education management is a very important part of the process of providing education in madrasas. To improve the quality of education in Indonesia, the government plays a role in organizing international standard educational institutions which include international standard schools or madrasas. International standard schools or madrasas are expected to be able to improve the quality of education in Indonesia. Students who can enter international standard schools or madrasas have followed my strict selection.

In addition to their ability to excel in academics, they must also master English and Information and Communication Technology. In general, it can be understood that the main objective of the International Standard School or Madrasah program is to improve the quality of education in Indonesia. Quality improvement as an implication of the existence of international standard educational institutions is of course hope for improving Indonesian education. These improvements are the hopes and aspirations of the establishment of an International Standard School or Madrasa. The existence of International Standard Schools or Madrasas that creates competition between schools is also unavoidable. The existence of an International Standard School or Madrasah makes schools direct all their resources to achieve the standard of obtaining the International Standard School or Madrasah status. Of course, this competition will be positive if the competition is related to the quality of education, not anything else.The Amanatul Ummah 
International Standard Madrasah which was developed in Pacet Mojokerto is one of the alternative solutions for implementing an education system that is responsive to the needs of the times in the era of globalization. This madrasa can answer various educational and learning problems. The International Standard Madrasah Amanatul Ummah Pacet is known as an educational institution at the level of a high school that seeks seriously, especially after getting QororMu'adah, which is a statement equated by the Al-Azhar College based in Egypt. To maintain the quality of Madrasahs by international quality standards, Amantul Ummah International Standard Madrasas must be able to control quality. From the observations, it is shown that the quality control process refers to the cooperation carried out by the leadership with the ranks in the madrasa in carrying out quality school management. Many obstacles are faced in controlling the quality of education management related to teaching and learning activities that can be relevant to the needs of the global and digital eraor able to meet the skills needs of the 21st century(Alismail \& McGuire, 2015).

The last study has described the improvement of quality education in madrasah or school. Madrasas have made a significant contribution to the lives of citizens in Indonesia. Therefore, the existence of madrasa education develops by the needs and demands of today's society(Zamroni, 2019). So, close cooperation and coordination between education components must be carried out efficiently and effectively to improve the quality of education(Anwar et al., 2019). Educational institutions must also be able to provide maximum service to students(Mashud et al., 2021), be open to development and fulfil quality assurance(Shodiq et al., 2017).Therefore, this study focuses on the concept of quality control management in the implementation of education in madrasas that have international standards. It is very important because the quality of education is the main factor in the implementation of education so that it still meets the standard values that have been set and can meet the needs of students in facing the challenges of getting into national and international quality universities. This gap study is presented on the concept of madrasa education which has a pesantren nuance and presents religious values. Thus, this research can provide benefits to the development of theories or concepts of improving education quality control in Madrasahs. So, the purpose of this study is to analyze and find the control of improving the quality of education in the International Standard Madrasah Amanatul Ummah Pacet Mojokerto, East Java.

\section{Conceptual Framework}

Control is an activity to research and measure and corrects the implementation of a plan that has been prepared so that it runs well.The control carried out with the orientation of quality improvement is a control system whose activities are the basic pillars with an orientation to quality principles.Juran has thought about quality as "fitness for use", oriented to the fulfilment of customer expectations. The cost of quality is determined by three costs, namely the cost of assessment, prevention, and failure (internal and external)(Juran, 2010).

a. Quality planning is a process to maintain customer loyalty by providing all their needs, developing products or services according to customer desires, and developing the production process of goods and services to be more efficient.

b. Quality control (quality control), is a process by which the product is checked and evaluated, compared to the needs desired by the customer.

c. Quality improvement is a process where appropriate mechanisms are maintained so that quality can be achieved sustainably.

There are five characteristics of a quality school such as customer focus, total involvement, measurement, commitment, and continuous improvement. Every educational institution including Islamic boarding schools is required to provide the best service to its customers(Indriyenni, 2017). Madrasas are Islamic educational institutions that have a positive character, traditions and local wisdom (local power) that continue to be carried out through amputation, minimization and assimilation(Faizin, 2020). So, the application of quality has become a culture and character(Rahmania et al., 2020). In the managerial realm, educational activities can be recognized as quality if they meet quality standards. Quality assurance in education is indeed influenced by elements of modern business management as a means to increase consumer confidence in education; namely the Implementation of Total Quality Management(Perdana \& Rohmat, 2021) 


\section{METHODOLOGY}

\section{Research Design}

This research was conducted to obtain an overview related to quality control management in primary education (madrasah) which has an international standard. It means that the research builds a new concept construction in education quality management. In this research design, it is associated with quality management of education at the International Standard Madrasah Amanatul Ummah, Mojokerto, East Java, through activities and behaviours that occur between the relationship between santri/students and santri, kyai and kyai, ustadz with ustadz or santri, kyai with ustadz and santri with kyai. From the behavioural relationship, it is constructed into an abstracted concept from a theory. The selection of the International Standard Madrasah Amanatul Ummah Mojokerto East Java is based on the characteristic that the Madrasah has 3 curricula, namely the national curriculum, mu'adah and the international curriculum. Thus, this research is a case study designed with a single case study model in qualitative research. This study related to the subjectivist and interpretive approach (Creswell, 2012)

\section{Population and Sampling}

The research was conducted at an educational institution, namely the Amanatul Ummah International Standard Madrasah Pacet Mojokerto, East Java. This educational institution is a high school level institution and has to get QororMu'adah, which is a statement equated by the Al Azhar College based in Egypt. This means that Madrasas have a quality that is equivalent to the implementation of the educational curriculum at Al-Azhar Higher Education Egypt. The criteria for selecting the International Standard Madrasah Amanatul Ummah are based on: 1) The International Standard Madrasah Amanatul Ummah Pacet Mojokerto is managed and organized by the pesantren, implements and develops the vision, mission and culture of the pesantren, but has an international brand. 2) improving the quality of education as an international standard madrasah has the following indicators, namely academic and non-academic achievements at the national and international levels; getting Qoror mu' is the acknowledgement of International Standard Madrasah Amanatul Ummah which is equated with educational institutions at alAzhar Egypt; the institution's ability to deliver its alumni for further studies at favourite universities at home and abroad.

The research sample was selected using purposive sampling. The participants involved in this study as interviewed informants were 1) kyai, 2) madrasa heads, 3) vice coordinators of Madrasas, 4) ustadzor teachers in Madrasas, 5) students, and 6) alumni. In the process of selecting participants using criteria that can meet the information needs of research data. Furthermore, kyai and madrasa heads are chosen on the grounds of being the top leaders who have the authority to plan and organize education. Here is the demographic of participants;

Table 1. Demographics of Participants

\begin{tabular}{|c|c|c|c|c|c|c|}
\hline $\begin{array}{c}\text { Informant's } \\
\text { Profile }\end{array}$ & Kyai & $\begin{array}{c}\text { Madrasah } \\
\text { Head }\end{array}$ & $\begin{array}{c}\text { Vice } \\
\text { Coordinators of } \\
\text { Madrasa }\end{array}$ & Teachers & Students & Alumni \\
\hline \multicolumn{7}{|l|}{ Gender: } \\
\hline Male & 1 (ASC) & $1(\mathrm{AC})$ & 1 (RI) & 15 & 25 & 75 \\
\hline Female & - & - & - & 15 & 25 & 75 \\
\hline \multicolumn{7}{|l|}{ Age: } \\
\hline Less than 25 & - & - & - & - & 50 & 100 \\
\hline $26-35$ & - & - & - & 15 & - & 50 \\
\hline $36-45$ & - & 1 & 1 & 15 & - & - \\
\hline Over than 46 & 1 & - & - & - & - & - \\
\hline \multicolumn{7}{|l|}{ Academic: } \\
\hline $\mathrm{PhD}$ & - & - & - & 3 & - & \\
\hline Master & 1 & 1 & 1 & 12 & - & 50 \\
\hline Bachelor & - & - & - & 15 & - & 100 \\
\hline Degree & & & & & & \\
\hline
\end{tabular}




\section{Instrument}

Interview sessions were conducted one by one face-to-face. The type of interview used is openended questions. It was conducted in three parts. The first part of the interview is related to the management of educational institutions from the leadership, namely the Kyai, the head of the madrasa, the vice coordinator of the madrasa. The information to be explored is how to monitor, evaluate programs, control activities, report activities, and monitor activities. Meanwhile, interviews with educators are related to the evaluation of learning programs and curriculum. For students and alumni, information related to learning and teaching activities in a holistic manner is explored.

For the observation activity, the researcher saw and listened to what the principal, vice coordinator, and teachers were doing. Observations were made related to the way of supervision, program evaluation, activity control, activity reports, and activity monitoring. The results of these observations are recorded as a record of field observations, which are then reflected.Documentation studies in this study are used to collect data as supporting data for research. Data from the documentation study will be used by researchers to understand and analyze the quality control management of education in madrasas.

\section{Data Collection Process}

Data collection techniques used 3 techniques that refer to the concept Bogdan and Biklen(Bogdan \& Biklen, 2007).This technique was chosen to obtain data holistically and integratively. These techniques include 1) in-depth interviews;2) participant observation;and 3) documentation study.

\section{Data Analysis}

The data analysis technique used three activity flows that can occur simultaneously, namely 1) data reduction, 2) data display;and 3) conclusion drawing/verification.

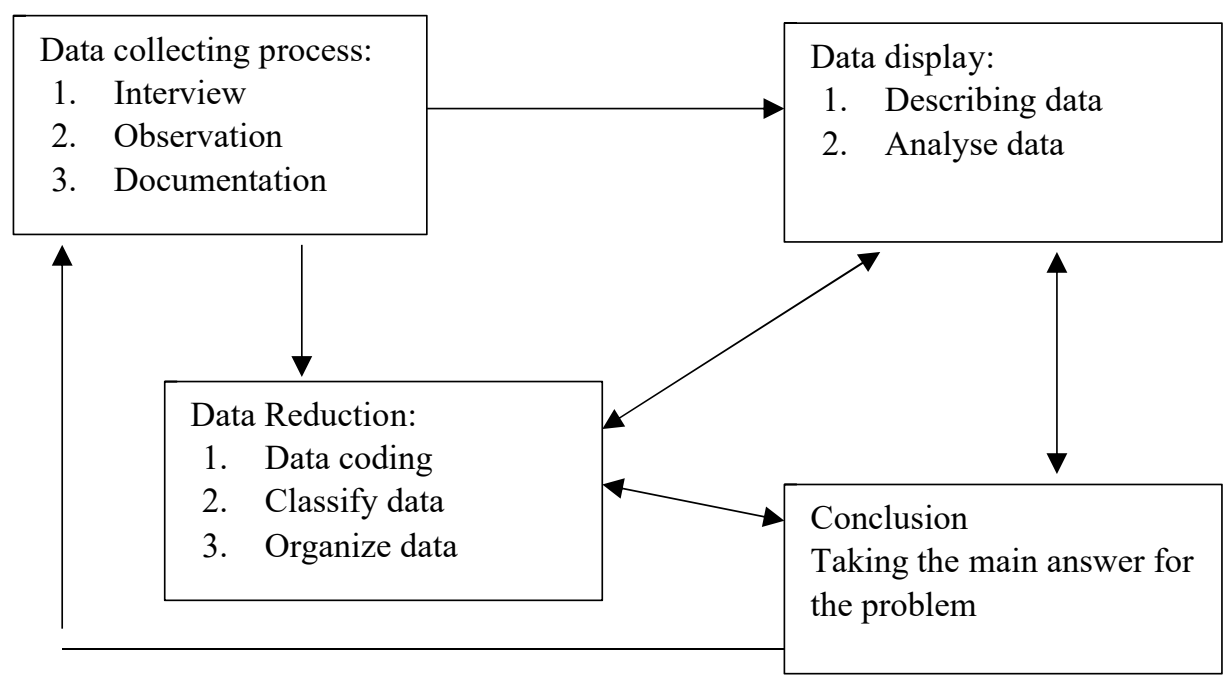

\section{Trustworthiness and Credibility}

This study emphasised the need for several measures to estab lish the trustworthiness and credibility of a qualitative study to minimise bias(Creswell, 2012). Checking the validity of the data in the study consists of;

1. The credibility test consists of steps; 1) the researcher re-checked the method used to collect data, 2) the researcher repeated the data on the research subject, and 3) the data triangulation process.

2. Transferability. In this case, the researcher will report the results of the research in detail. The findings are not part of a detailed description, but the interpretation of research data described in detail. The interpretation is carried out with full responsibility based on real events.

3. Dependability. This research involves auditors who act as data correctors so that the results of data analysis are credible.

4. Confirmability. The certainty of research data is done by confirming research data with informants or experts. This activity is carried out in conjunction with the dependability audit process. Therefore, the researcher returned to the research location and discussed the data that had been analyzed with the informants. 


\section{FINDING}

\section{Supervision}

Supervision is involved parties according to the type of activity. Quality improvement control is carried out directly by the coordinator and his team by adjusting to quality activities. This is as explained by the Kyai and the head of the madrasa through the following interview.

"The activities of the division are used as a reference for supervisory activities at Madrasas with International Standards. Examples of supervisory practices carried out at Madrasas with International Standards based on divisions are muhadarakubro activities which are carried out every 3 months and muhadarasughra once a month, so supervision is generally the responsibility of the Islamic boarding school division but specifically the responsibility of the language development division."

The reports provided are under the supervision of the vice coordinator of each division. The statement from the Kyai and the head of the madrasa was strengthened by the results of an interview with the vice coordinator on 27 May 2018.

\section{Evaluation}

The evaluation carried out at the Amanatul Ummah International Standard Madrasah was carried out through the following meetings. First, regular meetings, evaluation meetings are held every week. It is carried out routinely by all functionaries (name of vice coordinator). The weekly evaluation meeting is scheduled for every Wednesday night from $09.00-12.00$ p.m. This is as revealed from interviews with the principal, vice coordinator, and teachers;

"The Amanatul Ummah International Standard Madrasah conducts evaluation activities regularly through weekly, monthly and annual meetings. Annual meetings are held in the form of work meetings, monthly meetings are evaluation meetings by the entire teacher council, meetings held every week are functionaries and homeroom meetings, it is held every Wednesday night from nine o'clock in the evening until midnight. The meeting activity has been going on for a long time and was carried out without any invitation because it is obligatory by law ".

Monthly meetings consist of teacher council meetings and internal meetings of each vice coordinator and team.The implementation schedule follows the agreement or approval of each vice coordinator and team. The results of interviews with teachers stated that;

"The pesantren'sinternal meeting activities are incidental.For example, when a child is carrying a cellphone, an internal meeting must be held by the pesantren division."

\section{Control}

Control activities are carried out on the implementation of rules and regulations. The determination of these rules is by the concept of the Kyai which is called the seven keys to get success. So that, the control of activities in the madrasa can be controlled.As stated by Kyai and madrasa leaders in interviews:

"The internalization of transformative values at Amanatul Ummah is carried out through seven recipes called keys to get the success because they are sourced from Kyai.If one of the seven values is violated, in general, there will be room for violation in an even greater form.Here it is clear and detailed that the values are instilled in students must be implemented.It is to create quality education.So Amantul Ummah reforms by applying transformative values in a strict and controlled manner."

To control the quality of education, Amanatul Ummah also makes other efforts in the form of recycling. The term cycle is a control of the quality of education in the academic development of students. It influenced the exam result and students can pass $100 \%$ of the national exam, and can be accepted at several well-known universities according to their choice both at home and abroad. In addition, non-academic is a moral cycle. Non-academic Daurah is given to students who violate the rules or often violate them so that they need to be given sanctions or punishments. The sanction or punishment is adjusted to the background, cause, and form of the violation. This is as explained by the vice coordinator, teachers, students and alumni:

"Amanatul Ummah created a recycling program. This activity is intended for remedial teaching by repetition. There are two types of activities, the first is the academic cycle and the second is the non- 
academic cycle. The first type of daurah is carried out for students so that they can master the learning standards that have been set, and are carried out repeatedly until complete. The moral law is applied to children who commit many violations. The penalties imposed on violations adjust to take into account their psychic and heart sides. An example of punishment is in the form of cutting off vacation opportunities and then the punishment is given by serving for a few days to feel tired from working."

The description above is strengthened by data documentation of student performance systems. The document contains, among other things, the rules for giving punishments for coaching and taking on-the-spot actions that are given by giving direct punishments on the spot. While the violation is in the form of disciplinary action, it will be given guidance and action. Amanatul Ummah has the rule to discipline the students 24-hour, it is through daily attendance. The mechanism is to distribute attendance in each room at night and must be collected at night by the chairperson of the room who is assisted by WISSNU. Attendance is collected in the teacher's room. In addition, madrasas also put up banners at the entrance with large sizes and anything that is affixed to the walls of the mosque. The rules in the form of written student discipline consist of sub-rules containing the obligations and prohibitions of students while studying at the madrasa.

\section{Reporting}

Accountability reports are carried out by the results of weekly evaluations for programs that have been implemented, or programs that have not been implemented.The report also conveys the results of the evaluation along with obstacles, reasons, and policies. While verbal reports are carried out by providing guidance and direction during the implementation of activitieswhen something is not by the program. The results of the interview stated that;

"The control of the quality program in the form of reporting is carried out in writing in the form of an accountability report and verbally in the form of direction which is carried out by guiding the process of implementing activities and something is deemed inappropriate, it needs to be directed."

\section{Monitoring}

The activities of monitoring the quality of graduates at the Amanatul Ummah International Standard Madrasah can be identified as follows.

a. Monitoring quality control through the principles of quality standards, namely upholding culture and morals, maintaining trust and trustworthiness, and prioritizing humble values in establishing agreements.

"We prioritize the values of humble with trust. It means we depart from spiritual, and emotional. We will encourage intellectuals when the heart is formed. Facts turned outside the International Standard Madrasah".

b. Monitoring quality control through planned learning evaluations. The learning evaluation is carried out in several types, namely weekly, monthly, semester, and annual work meetings. Aspects that are evaluated in the implementation of the planned learning program include process activities and results. Process activities are carried out by relying on programs that have been carried out and become a habit (culture) at the Amanatul Ummah International Standard Madrasah. Evaluation of learning outcomes begins with an agreement on Minimum Learning Completeness Standards.Assessment of the teaching process, among others; (a) high student input; (b) high commitment and work ethic of teachers; (c) the existence of a conducive school climate; (d) senior teachers are always committed to transmitting a high work ethic to new teachers; (e) there is an increase in teacher professionalism through the activities of the Subject Teacher Consultation, training and workshops; (f) the effectiveness of tutoring for all students, and (g) the existence of achievement guidance.

c. Monitoring quality control through reports on the results of the International Standard Madrasah Amanatul ummah refers to the information obtained from the results of graduates who have registered at selected universities at home and abroad. Reports related to the success of graduates are carried out flexibly which are announced through websites, social media or banners related to the quality of graduates and some of the achievements that have been achieved by students. 
d. Monitoring quality control of graduates through controlling alumni who have been formed in the International Standard Madrasah Alumni Association and the Amanatul Ummah Alumni Association. The alumni who are members of the two forums hold meetings every year.

From the analysis data above, the following are the efforts to control quality management in the International Standard Madrasah Amanatul ummah.

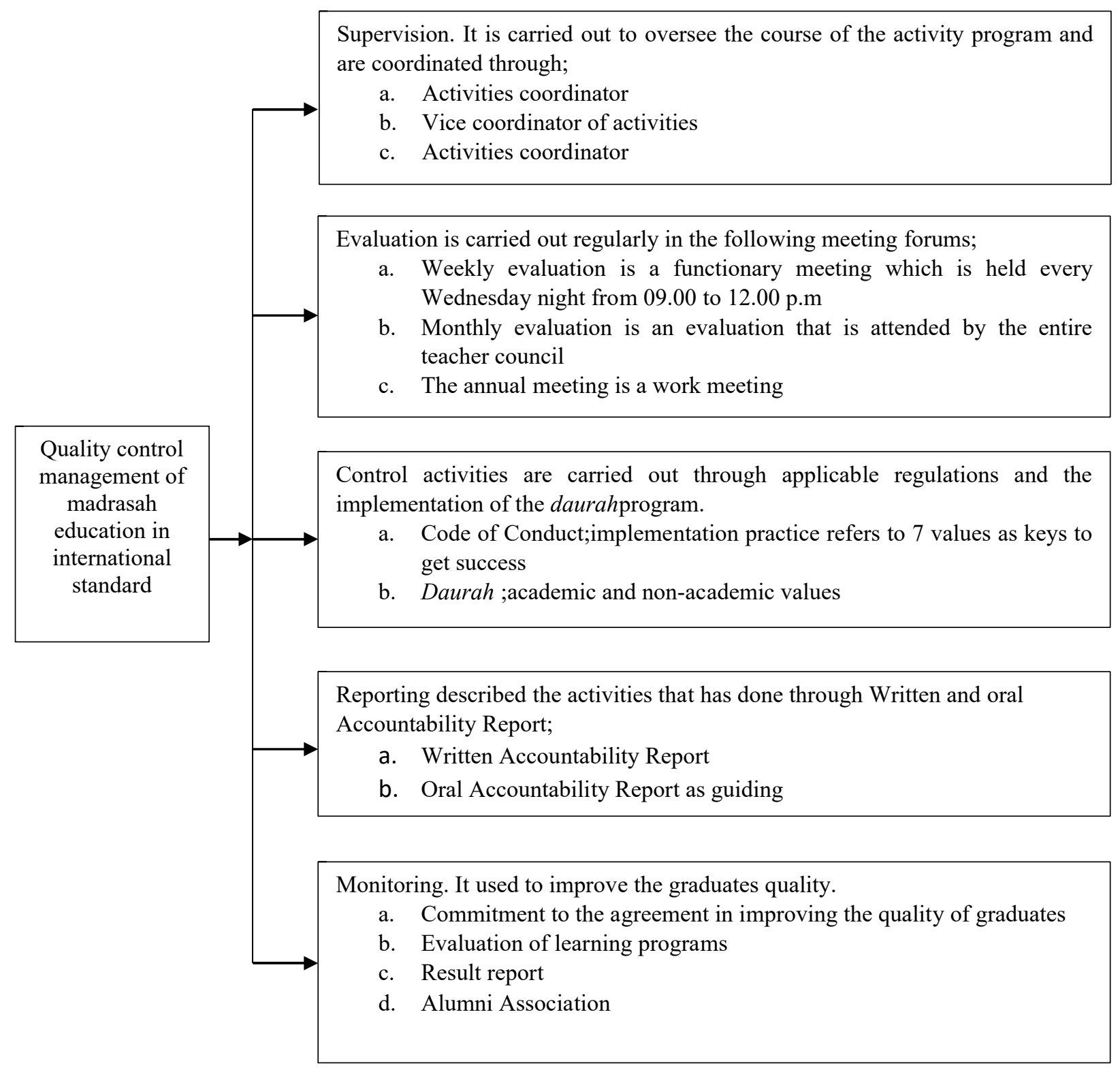

Fig 1. Concept of Quality Control Management of Madrasah Education Using International Standard

\section{DISCUSSION}

The findings indicate that the process of controlling the quality of education can be monitored(Altunay et al., 2013). Supervision (internal and external) is an important component of quality education(Briggs, 2012). The supervision carried out at the research location is coordinated supervision, which means that preventive-corrective-curative supervision is systematically carried out in a structured manner by involving the activity coordinator, vice activity coordinator and the person in charge of activities. But on the other hand, there is intangible supervision that is not contained in the formality system, namely inherent supervision which is indoctrinated in itself to all parties who are and are involved in the institution.The supervision carried out is a religious spirit that is instilled in everyone in the Amanatul Ummah International Standard Madrasah. This supervision is based on the fact that wherever humans are, they are always supervised by the All-Seeing One, namely Allah SWT. This value is very strongly instilled 
and is transcendent.All components related to quality control run in cycles. The control components include monitoring program activities, routine evaluations, program control, academic and non-academic activities, direct and indirect monitoring. It is related to local and national supervision (Kotirde \& Yunos, 2015; Demina et al., 2020).

The findings also show that education quality management control has become part of the implementation of Madrasah management which includes;

[1] Planning quality. The Amanatul Ummah International Standard Madrasah has carried out planning based on a combination of the design of the vision and mission of educational institutions with the transformation of Islamic boarding school values to give birth to a generation of Muslims who are intelligent, transformative and have an international perspective. Planning is based on the need for quality standards of character. In addition, Amanatul Ummah has also built an educational mindset that is not only related to the results of academic scores but also prioritizes the realm of mental and spiritual social development. Madrasahs can apply the Total Quality Management System in educational planning and organization and other processes important to education(Larina, 2015; Sallis, 2011). Historically, education quality assurance has been influenced by elements of modern business management as a means to increase consumer confidence in education; namely by implementing Total Quality Management(Perdana \& Rohmat, 2021). TQM can also form a society that is responsive to the changing demands of society in this era of globalization. In addition, TQM forms schools that are responsive and able to respond to change(Indriyenni, 2017)

[2] Quality Control is carried out through supervision, evaluation, control, activity reports, monitoring activities.

[3] Quality improvement related to visionary leadership, management commitment, solid team. Evaluation is carried out according to standards and can be accounted for, quality awareness socialization in all elements, integrating science with Islamic teachings(Roy et al., 2020)

Quality improvement in Madrasas with International Standards of Amanatul Ummah has been carried out theoretically which refers to the fundamentals of the international context in providing education(Pisoňová \& Nagyová, 2014). Several things related to quality improvement that has been carried out at Amantul Ummah are 1). The use of English and Arabic between teachers and students and mastery of Information and Communication Technology. 2). Integrated quality improvement through institutional innovation, curriculum and learning that integrates science with Islamic teachings. 3). The concept of solid teamwork in an organization. 4). Provision of appropriate learning facilities and infrastructure. Materials in the form of learning materials are applied by integrating general science and religion. 5). Quality control of International Standard Madrasah education is carried out by evaluating learning programs, namely at the time the learning takes place. The quality of madrasa education depends on many factors such as the leadership of the principal which is very decisive and influences other supporting factors in maintaining and securing the quality of madrasa education(Nursaid, 2020). Evaluation of this learning program begins with monitoring. Aspects evaluated include process and results. Evaluation is carried out as a process to determine conformity to products, objectives, procedures, programs, approaches and functions. There are three evaluation keywords, namely process, consideration and value. So, evaluation is a process carried out on an activity. Activities can be in the form of a program that has been planned. Furthermore, to determine the success of the program, it is necessary to carry out an assessment process. Evaluation as a process is the preparation of data for decision-makers.6). Creating a conducive environment.

While in the realm of learning, Amantul Ummah has also assessed quality control. This is done with a purpose; 1. Description of student learning skills 2. The success of the education and learning process in schools can be known. 3. Make improvements and refinements to education and learning programs and their implementation strategies 4. Accountability of the school to interested parties. Evaluation of achievement is used to see the effectiveness of the learning process in seeking changes in student behaviour. The process of quality control through the processes above is a comprehensive effort to carry out the process. So, madrasas have emphasized Quality Control which lies in product testing. So, controlling the quality improvement of Madrasah with International Standards of Amantul Ummah is carried out starting from the input (on raw 
material input); controlling the process of implementing education by integrating science and Islam, and also controlling the outcomes of students and graduates. Thus, it can be concluded that the control of improving the quality of education carried out by the Amanatul Ummah International Standard Madrasah is internal and transcendent control.

\section{IMPLICATION AND RECOMMENDATION}

The results of this study have implications for improving the quality of education in Madrasahs by integrating knowledge with Islamic values,internalizing and transforming Islamic Boarding School values into students. In addition, the results of the study also describe the concept of international standard education through the transformation of Islamic values in Islamic boarding schools and also scientific integration. Furthermore, the results of the study relate to the quality assurance process for formal educational institutions in the Islamic boarding school environment. At the International Standard Madrasah, Amanatul Ummah has implemented baroque quality assurance. So, there is a fundamental value in the implementation of formal education at the Amanatul Ummah International Standard Madrasa which upholds Islamic values.

Thus, quality management at the Amanatul Ummah International Standard Madrasah used Ishikawa's theory with the transformation of Islamic values so that the new variant of the theory is called Quality Management of Adopt Transformation in PDCA Based Islamic Value. Based on the pillars of the idea of change, pesantren should be responsive to changes and developments of the times. The response to the changes and developments of the times can be realized in various ways, such as establishing formal educational institutions, making changes to the learning system and others. However, changes and developments must not eliminate the basic value of Islamic boarding schools, namely passing on traditions. The results of the study suggest that further research should develop aspects of quality control in the management of educational institutions that are relevant to the development of science and technology. Also, the principal or madrasah in the pesantren environment should carry out the continuous quality improvement. The researcher realizes that this research is still limited so further activities can lead to the internalization of the pesantren tradition for formal schools in the pesantren environment.

\section{CONCLUSION}

The results of data analysis concluded that the process of controlling the quality of education in Madrasas with international standards was carried out through five aspects, namely supervision, evaluation, control, regular reporting and monitoring of activities that have been carried out. From the data findings, it is known that;

1. Control of improving the quality of education is effective if the supervision is carried out in a coordinated and responsible manner.

2. Control of improving the quality of education is effective if there is a series of evaluations carried out intensely and periodically.

3. Control of improving the quality of education is effective if there is control carried out continuously.

4. Control of improving the quality of education is effective if there is written and verbal accountability.

5. Control of improving the quality of education is effective if monitoring efforts are carried out on an ongoing basis.

6. Quality control is stronger when it is implemented with an internal and transcendent system with the inherent supervision spirit of God's teachings.

\section{REFERENCES}

[1] Alismail, H. A., \& McGuire, P. (2015). 21st Century Standards and Curriculum: Current Research and Practice. Journal of Education and Practice, 6(6), 150-155.

[2] Altunay, E., Arlı, D., Öz, Y., \& Yalçınkaya, M. (2013). Continuity in Educational Supervision: A Case Study. Procedia - Social and Behavioral Sciences, 106, 723-729. https://doi.org/10.1016/j.sbspro.2013.12.083

[3] Anwar, L. M., Jufri, A. W., \& Muhaimi, L. (2019). Application of Madrasah Based Management in Improving 
the Quality of Aliyah Madrasah Education. International Journal of Multicultural and Multireligious Understanding, 6(5), 257-269. https://doi.org/10.18415/IJMMU.V6I5.1086

[4] Bogdan, R., \& Biklen, S. K. (2007). Qualitative Research for Education: An Introduction to Theories and Methods. Pearson Education Inc.

[5] Briggs, F. (2012). Enhancing Quality Education in Nigerian Unity Schools through Effective Supervision in a Changing Environment. Journal of Education and Vocational Research, 3(10), 332-335. https://doi.org/10.22610/jevr.v3i10.86

[6] Creswell, J. W. (2012). Educational Research: Planning, Conducting, and Evaluating Quantitative and Qualitative Research. Pearson Education.

[7] Demina, V., Demina, S., Kozhukalova, O., \& Zayakina, I. (2020). Quality of education as a requirement of modern society. E3S Web of Conferences, 210. https://doi.org/10.1051/E3SCONF/202021022031

[8] Faizin, F. (2020). PENGELOLAAN MUTU PENDIDIKAN DALAM PENGEMBANGAN MADRASAH TSANAWIYAH. PEDAGOGIK: Jurnal Pendidikan, 7(1), 47-73. https://doi.org/10.33650/PJP.V7I1.1009

[9] Indriyenni, I. (2017). TOTAL QUALITY MANAGEMENT IN ISLAMIC EDUCATION INSTITUTION. Ta'dib, 20(1), 51-61. https://doi.org/10.31958/JT.V20I1.753

[10] Juran. (2010). Juran's Quality Handbook, Sixth Edition features. McGraw-Hill Education.

[11] Kotirde, I. Y., \& Yunos, J. B. M. (2015). The Processes of Supervisions in Secondary Schools Educational System in Nigeria. Procedia - Social and Behavioral Sciences, 204, 259-264. https://doi.org/10.1016/j.sbspro.2015.08.149

[12] Larina, L. N. (2015). Practical Application of Total Quality Management System to Education of International Students. Procedia - Social and Behavioral Sciences, 215, 9-13. https://doi.org/10.1016/j.sbspro.2015.11.566

[13] Mashud, I., Suradika, A., \& Ahmad, G. (2021). QUALITY MANAGEMENT OF ISLAMIC EDUCATIONAL INSTITUTIONS SERVICE (STUDY OF CUSTOMER SATISFACTION ANALYSIS IN MADRASAH IBTIDAIYAH AL-HUSNA CILEDUG TANGERANG CITY). International Journal of Educational Management and Innovation, 2(1), 55-67. https://doi.org/10.12928/IJEMI.V2I1.3007

[14] Nursaid, N. (2020). The Leadership of Headmaster in Improving the Quality of Madrasa Education. Jurnal Pendidikan Islam, 6(1), 95-108. https://doi.org/10.15575/JPI.V6I1.3410

[15] Perdana, M. N., \& Rohmat, R. (2021). History of Quality Managemen in Education. EduTech: Jurnal Ilmu Pendidikan Dan Ilmu Sosial, 7(2), 225-230. https://doi.org/10.30596/EDUTECH.V7I2.7291

[16] Pisoňová, M., \& Nagyová, A. (2014). The Auto-evaluation in the Process of Improving the Quality of Educational and Non-educational Institutions. Procedia - Social and Behavioral Sciences, 149, 724-732. https://doi.org/10.1016/j.sbspro.2014.08.278

[17] Rahmania, I., Budiono, B., Soenaryo, S. F., Syakur, A., \& Tinus, A. (2020). Implementation of Internal Quality Guarantee System to Increase the Quality of Education in Junior High School 21 Malang. Budapest International Research and Critics in Linguistics and Education (BirLE) Journal, 3(1), 421-432. https://doi.org/10.33258/BIRLE.V3I1.838

[18] Roy, S., Huq, S., \& Rob, A. B. A. (2020). Faith and education in Bangladesh: A review of the contemporary landscape and challenges. International Journal of Educational Development, 79, 102290. https://doi.org/10.1016/J.IJEDUDEV.2020.102290

[19] Sallis, E. (2011). Total Quality Management in Education (Manajemen Mutu Pendidikan), terj. Ahmad Ali Riyadi \& Fahrurrozi. IRCiSoD.

[20] Shodiq, M., Shodiq, M., Suyata, S., \& Wibawa, S. (2017). Developing quality evaluation instrument for Islamic Senior High School. Jurnal Penelitian Dan Evaluasi Pendidikan, 21(2), 189-205. https://doi.org/10.21831/pep.v21i2.15675

[21] Zamroni, Z. (2019). Innovation of Learning Management in Madrasah Level. Dinamika Ilmu: Jurnal Pendidikan, 19(2), 337-349. https://doi.org/10.21093/DI.V19I2.1717 